\title{
Competition Between Humic Substances and $\alpha$-Amino Acids by Metal Species
}

\author{
Ademir dos Santos ${ }^{*, a, b}$, Iramaia C. Bellin ${ }^{b}$, Pedro Paulo Corbi ${ }^{b}$, Alexandre Cuin ${ }^{b}$, André Henrique \\ Rosa $^{c}$, Maria Olimpia de O. Rezende ${ }^{a}$, Julio Cesar Rocha ${ }^{b}$ and Petr Melnikov ${ }^{d}$ \\ ${ }^{a}$ Instituto de Química de São Carlos, Universidade de São Paulo, CP 780, 13561-140 São Carlos - SP, Brazil \\ ${ }^{b}$ Instituto de Química, Universidade Estadual Paulista, CP 355, 14801-970 Araraquara - SP, Brazil \\ ${ }^{c}$ Departamento de Engenharia Ambiental, Universidade Estadual Paulista, 18087-180 Sorocaba - SP, Brazil \\ ${ }^{d}$ Universidade Federal do Mato Grosso do Sul, 79070-900, Campo Grande - MS, Brazil
}

\begin{abstract}
O objetivo deste trabalho foi comparar a complexação de substâncias húmicas (SH) e $\alpha$-aminoacidos (metionina, metionina sulfoxido e cloridrato de cisteína) por elementos traço de interesse biológico (Al, $\mathrm{Cu}, \mathrm{Pb}, \mathrm{Mn}, \mathrm{Zn}, \mathrm{Cd}$ e Ni). Sistema de ultrafiltração tangencial foi utilizado para diferenciação entre os complexos SH-metal e $\alpha$-aminoácidos-metal. As determinações de metal foram feitas utilizando ICPOES. Os resultados mostraram que as $\mathrm{SH}$ podem ser consideradas agentes complexantes seletivos com alta capacidade de complexação a $\mathrm{Al}, \mathrm{Cu}$ e $\mathrm{Pb}$, podendo ser clinicamente importante.
\end{abstract}

The aim of the present work was to carry out experimental comparison between humic substances (HS) and representative $\alpha$-amino acids (methionine, methionine sulfoxide and cysteine hydrochloride) in relation to the complexation of biologically active trace elements ( $\mathrm{Al}, \mathrm{Cu}, \mathrm{Pb}, \mathrm{Mn}, \mathrm{Zn}, \mathrm{Cd}$ and $\mathrm{Ni}$ ). A mobile time-controlled tangential-flow UF technique was applied to differentiate between HSmetal and $\alpha$-aminoacids-metal complexes. Metal determinations were conventionally carried out using a ICP-OES. The results showed that HS may be considered as a selective complexing agents with higher metal bonding capability in relation to $\mathrm{Al}, \mathrm{Cu}$ and $\mathrm{Pb}$, the fact that may be clinically important.

Keywords: humic substances, soils, metals, $\alpha$-amino acids

\section{Introduction}

Amino acids, especially sulfur-containing $\alpha$-amino acids and their esters are known as coordinating agents for metal ions due to the presence of amino $\left(\mathrm{NH}_{2}\right)$, carboxylate $(\mathrm{COO})$ and carbonyl $(\mathrm{C}=\mathrm{O})$ groups in their structures. ${ }^{1-3}$ There are in the literature numerous tables and databases where stability constants of many metal ions with a great number of $\alpha$-amino acids. ${ }^{4,5}$ Actually, the $\alpha$-amino acids have been widely tested as chelating agents in order to obtain physiologically compatible, safer drugs and antidotes for the cases of acute poisoning after ingestion of heavy metals. Using this approach remedies against rheumatoid arthritis, Wilson's disease and other invalidating conditions were found and actually are being used in clinical practice. ${ }^{6}$ However, pure sulfur-containing amino acids are extremely expensive and effective only in

\footnotetext{
* e-mail: ademir@iq.unesp.br
}

injectable forms. So the development of new drugs ought to be centered preferentially on the products of natural origin having the same or more varied functional groups.

Humic substances (HS) seem to fit these requirements and guarantee the complexation capability since they possess a great variety and number of functional groups, mainly carboxylic and hydroxylic sites suitable for metal ions fixation. ${ }^{7,8}$ Heavy metal complexation by HS has been studied through various approaches that have been proposed such as ion-selective electrode (ISE), polarography and voltametry methods, fluorescence quenching and ultrafiltration procedures. ${ }^{7-9}$ Actually, HS has been used as anti-inflammatory, antiviral and even estrogen-like agents with relatively good results. ${ }^{10,11}$ It was also shown by Herzig et al. ${ }^{12}$ that the administration of sodium humate to animals reduces cadmium concentrations in organs. Sodium humate is incorporated into liposomes after having crossed the skin barrier, the fact explaining encouraging results of peat therapy known over a considerable time. ${ }^{13}$ 
The aim of the present work is to carry out experimental comparison between HS and representative $\alpha$-amino acids (methionine, methionine sulfoxide and cysteine hydrochloride) showed in Figure 1, in relation to the complexation of biologically active trace elements (Al, $\mathrm{Cu}, \mathrm{Pb}, \mathrm{Mn}, \mathrm{Zn}, \mathrm{Cd}$ and $\mathrm{Ni}$ ).

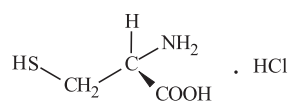

Cysteine hydrochloride

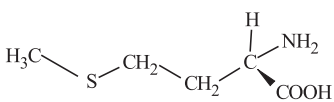

Methionine<smiles>CS(=O)CCC(N)C(=O)O</smiles>

Methionine sulfoxide

Figure 1. Schematic structure of the $\alpha$-amino acids used on the present work.

\section{Materials and Methods}

\section{Chemicals and reagents}

All reagents used were of high-purity grade unless otherwise stated. Working solutions of acids were prepared by diluting 30\% hydrochloric acid (suprapur, Merck AG) and $65 \%$ nitric acid (p.a. Merck AG, pre purified by sub boiling distillation) with high-purity water (Milli-Q system, Millipore). The same water was used for preparing sodium hydroxide solution using monohydrate, $\mathrm{NaOH}_{2} \mathrm{H}_{2} \mathrm{O}$ (suprapur, Merck AG). For calibrations and metal determinations appropriate synthetic standard (ICP multielement standard solution IV, Merck AG) was employed.

\section{Extraction of humic substances}

The samples of soil were collected in Araraquara region, São Paulo State, Brazil. The HS were extracted according to the procedure recommended by International Humic Substances Society. ${ }^{14}$ For this purpose, the dried soil samples were ground and passed through a $2 \mathrm{~mm}$ sieve. 200 grams of the resulting material were extracted with a volume of $0.1 \mathrm{~mol} \mathrm{~L}^{-1} \mathrm{HCl}$ solution equal to ten times the weight of the sample. The $\mathrm{pH}$ of the solution was adjusted between 1.0 and 2.0 with $1.0 \mathrm{~mol} \mathrm{~L}^{-1} \mathrm{HCl}$ solution. The soil/ $\mathrm{HCl}$ mixture was shaken for $1 \mathrm{~h}$ and the suspension allowed to settle. The mixture was centrifuged at $1478 \mathrm{~g}$ for $10 \mathrm{~min}$, and the supernatant was separated from the sediment. The sediment was neutralized with $1.0 \mathrm{~mol} \mathrm{~L}^{-1}$
$\mathrm{NaOH}$ solution to $\mathrm{pH} 7.0$, and a volume of $0.1 \mathrm{~mol} \mathrm{~L}^{-1}$ $\mathrm{NaOH}$ solution equal to ten times the weight of the sample was added under nitrogen atmosphere. The mixture was shaken for $4 \mathrm{~h}$ and then allowed to settle over night. The supernatant was separated from the sediment by centrifugation at $1478 \mathrm{~g}$ for $10 \mathrm{~min}$, and the sediment discarded. The supernatant (HS) was evaporated in vacuum and dried in circulating air oven at $55^{\circ} \mathrm{C}$.

\section{Purification of humic substances}

Samples of the HS were transferred into dialysis tubes and dialyzed against water in order to eliminate soluble salts. The external water was replaced three times after 3-5 $\mathrm{h}$ and then every $12 \mathrm{~h}$ until no $\mathrm{Cl}^{-}$could be detected. Subsequently the HS were evaporated in vacuum and dried in circulating air oven at $55^{\circ} \mathrm{C}$.

\section{Experimental procedure}

Complexing activity of HS and the a-amino acids $v s$. metal ions were compared by using an ultrafiltration system (Figure 2) that proved to be useful for analytical purposes such as protein separation and determination of stability constants. ${ }^{15}$ This procedure allows to block the passage of HS, which have high molecular size, as well as their complexes, through the flat ultrafiltration membrane (Gelman Pall-Filtron OMEGA, cut-off $1 \mathrm{kDa}$ ), while the amino acids have no impediments to pass throughout. Previously were prepared and mixed together $40 \mathrm{~mL}$ of $\mathrm{HS}$ solution $\left(0.5 \mathrm{mg} \mathrm{mL}^{-1}\right)$ and $10 \mathrm{~mL}$ of multielement standard solution (20 $\mathrm{mg} \mathrm{L}^{-1}$ of $\mathrm{Al}, \mathrm{Cu}, \mathrm{Pb}, \mathrm{Mn}, \mathrm{Zn}, \mathrm{Cd}$ and $\mathrm{Ni}$ ). Then the $\mathrm{pH}$ was adjusted to 5.0 by $0.1 \mathrm{~mol} \mathrm{~L}^{-1} \mathrm{NaOH}$ solution, water was added until a final volume $190 \mathrm{~mL}$ and the resulting mixture shaken for $24 \mathrm{~h}$ in order to attain

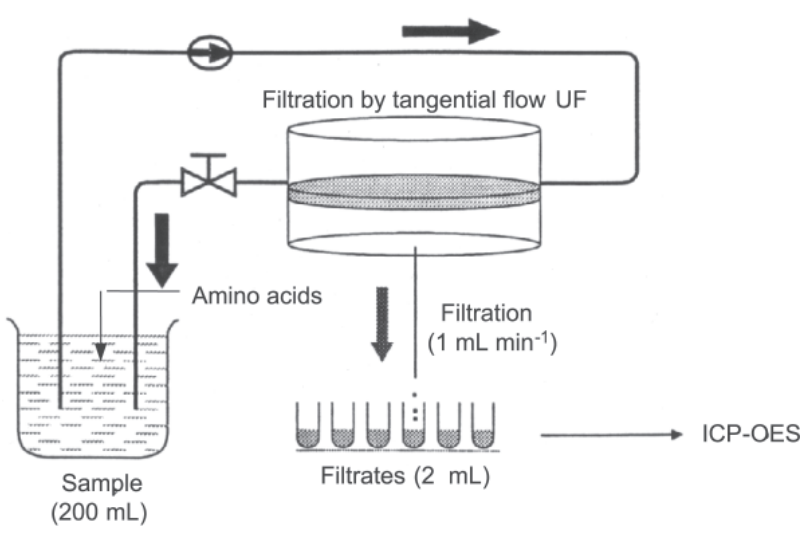

Figure 2. Scheme of analytical approach used to study comparative affinities of humic substances and a-amino acids in relation to metal ions. 
equilibrium. The mixture was circulated through the system and a small volume $(\cong 2.0 \mathrm{~mL})$ of it was removed after filtration in order to fix the zero time. This sample contains free metal ions that had not been retained by HS. Then 10 $\mathrm{mL}$ of the solution containing amino acids $\left(3.0 \mathrm{mmol} \mathrm{L}^{-1}\right)$ was added to the circulating mixture and after given time intervals $(5,10,20,30,60120,180,240,360,720$ e 1440 min) filtrates were taken out and the metal ions concentrations determined.

\section{Metal determinations}

The humic substances solution with original metal (Al: 3.18, Cd: 0.21, Cu: 0.53, Mn: 0.38, Ni: 0.50; Pb: 0.31 and Zn: $0.09 \mathrm{mg} \mathrm{L}^{-1}$ ) and fractions containing $\alpha$-amino acidsmetal complexes were acidified with dilute $\mathrm{HNO}_{3}$ and metals content determined simultaneously by means of ICP-OES (Inductively Coupled Plasma- Optical Emission Spectrometer, Thermo Jarrell Ash IRIS-DUO spectrometer) according to the recommendations of the manufacturer.

\section{Results and Discussion}

In the Table 1 are shown the proportions of metal ions retained by $\mathrm{HS}$ in the absence (deionized water) and presence of methionine, methionine sulfoxide and cysteine hydrochloride after equilibrium has been attained. It shows that $\mathrm{Cu}, \mathrm{Pb}$, and specially $\mathrm{Al}$, have a remarkable affinity to HS while the amino acids bond preferentially $\mathrm{Mn}, \mathrm{Zn}, \mathrm{Ni}$ and $\mathrm{Cd}$. In accordance with these results, the following orders of metal ions retained for HS in contrast to different amino acids have been established: (i) methionine: $\mathrm{Al}>$ $\mathrm{Pb}>\mathrm{Cu}>\mathrm{Cd}>\mathrm{Ni}>\mathrm{Mn}>\mathrm{Zn}$; (ii) methionine sulfoxide: $\mathrm{Al}>$ $\mathrm{Pb}>\mathrm{Cu}>\mathrm{Ni}>\mathrm{Cd}>\mathrm{Zn}>\mathrm{Mn}$ and (iii) cysteine hydrochloride: $\mathrm{Al}>\mathrm{Pb}>\mathrm{Cu}>\mathrm{Ni}>\mathrm{Cd}>\mathrm{Mn}>\mathrm{Zn}$.

The kinetic of extraction from HS phase is illustrated by graphics of complexation showing similar profiles for three a-amino acids (Figures 3). It is slow for the first group, $\mathrm{Cu}$ and $\mathrm{Pb}$, with reaction times starting from 5-10 min, while the second group, $\mathrm{Zn}, \mathrm{Mn}, \mathrm{Cd}$ and $\mathrm{Ni}$, show faster interaction attaining the equilibrium in about $60 \mathrm{~min}$.
Aluminum bonding to HS seems to be the strongest for all aminoacids studied since practically no aluminum was detected in the liquid phase.

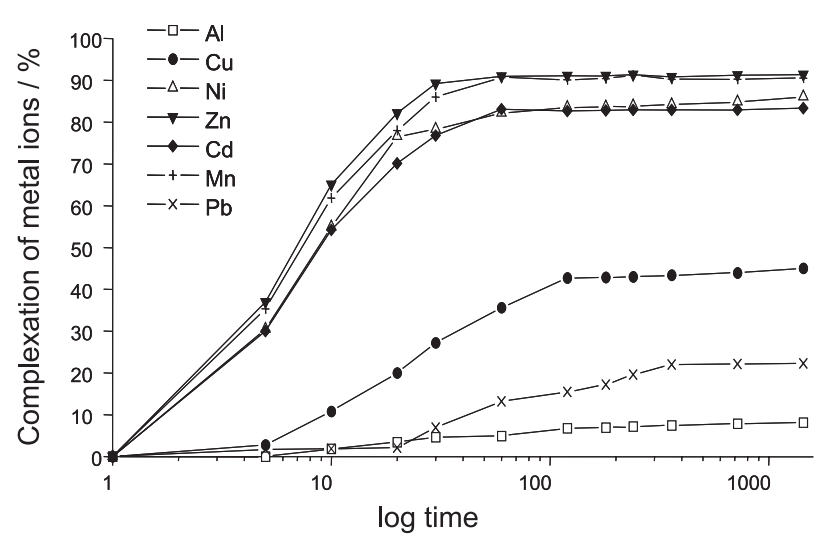

Figure 3. Complexation of metal ions in presence of L- methionine.

The most powerful complexant seems to be cysteine hydrochloride, in all probability owing to the presence of thiol groups. Since aluminum is considered as a risk factor in Alzheimer's disease and other dementias ${ }^{16,17}$, cutaneous applications of HS-containing material may prove useful for reducing contents of this metal in the body. In the cases of acute $(\mathrm{Pb})$ and chronic $(\mathrm{Pb}, \mathrm{Cu})$ poisonings $\mathrm{HS}$ may be extremely valuable in the form of a suspension since they are not capable to pass through gastric wall and enter into bloodstream, in contrast to the majority of conventional antidotes.

\section{Conclusion}

Humic substances, in comparison with L-methionine, methionine sulfoxide and cysteine hydrochloride, may be considered as a selective complexing agents with higher metal bonding capability in relation to $\mathrm{Al}, \mathrm{Pb}$ and $\mathrm{Cu}$. Neutral character and high molecular mass of humic substances permit to forecast their usage in clinical practice, in the form of cutaneous applications and suspensions for internal usage.

Table 1. Proportion of metal ions retained by HS in presence of the $\alpha$-amino acids (\%)

\begin{tabular}{lccccccc}
\hline Amino acids & & \multicolumn{3}{c}{ Metal ions } & & & \\
& $\mathrm{Al}$ & $\mathrm{Cu}$ & $\mathrm{Pb}$ & $\mathrm{Mn}$ & $\mathrm{Zn}$ & $\mathrm{Ni}$ & 14.07 \\
\hline Methionine & 91.80 & 55.02 & 77.70 & 9.44 & 8.68 & 16.63 \\
Methionine sulfoxide & 95.15 & 60.17 & 82.95 & 3.84 & 4.44 & 16.40 & 16.16 \\
Cysteine hydrochloride & 95.71 & 77.55 & 83.25 & 9.91 & 4.99 & 24.37 & 22.66 \\
\hline
\end{tabular}

${ }^{a}$ These results were calculated considering the metals removed by deionized water (absence of the $\alpha$-amino acids) in the zero time. 


\section{Acknowledgements}

This work was financially supported by Fundação de Amparo à Pesquisa do Estado de São Paulo, Conselho Nacional de Desenvolvimento Científico e Tecnológico and FUNDUNESP (Brazilian agencies). A. Santos is also thankful the International Humic Substances Society by Travel Bursary to present this work in the 10th International Meeting of the Humic Substances (Boston, August 2002).

\section{References}

1. Alfasser, R.; Rau, T.; Van Eldik, R.; J. Inorg. Biochem. 1995, 59, 167.

2. Nemirovskiy, O.V.; Gross, M.L.; J. Amer. Soc. Mass Spec. 1996, 7, 977.

3. Criado, J.J.; Rodríguez-Fernández, E.; García, E.; Hermosa, M.R.; J. Inorg. Biochem. 1998, 69, 113.

4. Martell, A.E.; Smith, R.M.; Critical Stability Constants, Plenum Press: New York, vol. 1, 1974.

5. Berthon, G.; Pure Appl. Chem. 1995, 67, 1117.

6. Klaassen, C.D. In The Phamacological Basis of Therapeutics; Hardman, J.G.; Limbird, L.E.; Molinoff, P.B.; Ruddon, R.W.; Gilman, A.G., eds., $9^{\text {th }}$ ed., McGraw-Hill: New York, 1996, pp.1649-1671.

7. Lubal, P.; Siroky, D.; Fetsch, D.; Havel, J.; Talanta 1998, 42, 401.
8. Lubal, P.; Fetsch, D.; Siroky, D.; Lubalova, M.; Senkyr, J.; Havel, J.; Talanta 2000, 51, 977.

9. Romão, L.P.C.; Castro, G.R.; Rosa, A.H.; Rocha, J.C.; Padilha, P.M.; Silva, H.C.; Anal. Bioanal. Chem. 2003, 375, 1097.

10. Nastos, V.; Garagounis, M. In Moortherapie 2000 - Peat Therapy on it's Way Into the Next Millenium. Bad Kissinger; Beer, A.M.; Lüttig, G.; Lukanov, J. eds., Publisher: Greece, 2000, pp.202-208.

11. Klöcking, R. In Humic Substances in the Global Environment and Implications on Human Health; Senesi, N.; Miano, T. eds.; Elsevier: Amsterdam, 1994, pp.1245-1257.

12. Herzig, I.; Hampl, J.; Docekalova, H.; Pisarikova, B.; Vlcek, J.; Vet. Med. 1994, 39, 175.

13. Hampl, J.; Herzig, I.; Vlcek, J.; Vet. Med. 1994, 39, 305.

14. Rosa, A.H.; Vicente, A.A.; Rocha, J.C.; Trevisan, H.C.; Fresenius J. Anal. Chem. 2000, 368, 730.

15. Burba, P.; Van den Bergh, J.; Klockow, D.; Fresenius J. Anal. Chem. 2001, 371, 660.

16. Flaten, T.P.; Brain Res. Bull. 2001, 55, 187.

17. Yase, Y.; Yoshida., S.; Kihina, T.; Neuropath. 2001, 21, 105.

Received: September 23, 2003

Published on the web: April 30, 2004

FAPESP helped in meeting the publication costs of this article. 